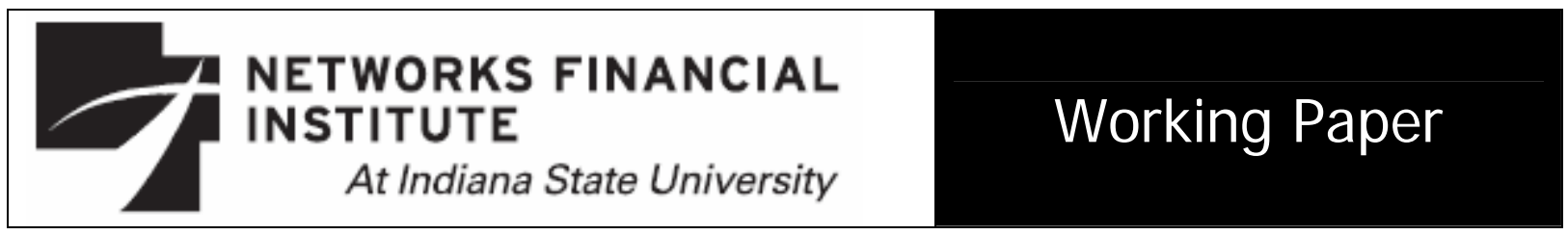

2007-WP-16

April 2007; revised J uly 2007

\title{
Social Security, Intergenerational Transfers, and Saving: New Evidence from an Emerging Country \\ H. Yigit Aydede
}

\begin{abstract}
Because of the several shortcomings of aggregate time-series investigations, cross-section studies outnumber the time-series analyses on the relationship between saving and Social Security. This study is the first of its kind for an emerging country that examines the subject at two major points: (1) by using aggregate social security wealth simulations, it formally shows that the PAYG system in Turkey constitutes significant wealth redistributions of resources among different age cohorts; (2) instead of applying traditional wealth functions to observe whether social security wealth displaces non-pension wealth in cross-section setting, it investigates whether or not households' consumption behavior exhibits a life-cycle pattern by using the Household Labor Force Survey conducted in 2002 for more than eight thousand households. The results confirm that marginal propensity to consume (MPC) out of total resources is significantly different for different age cohorts.

Because of its strong Ponzi scheme structure and the fact that it involves resource transfers between different age cohorts we conclude that the Turkish PAYG system may suppress the national saving in Turkey.
\end{abstract}

About the Author: Yigit Aydede is Assistant Professor of Economics at the Sobey School of Business at Saint Mary's University in Halifax. Previously he was at the University of Windsor, Canada. He received his MBA degree in 2004 and his PhD degree in economics in 2006, both from the University of Delaware. In addition to long business experience in banking and insurance sectors, he has extensive university teaching experience. His research interests include the economics of aging, social security, public finance, and applied macroeconomics. His present research focuses on the public social security systems in developing countries. He is currently investigating the effects of unfunded social security systems on intergenerational resource transfers and labor force participation under developing country conditions.

Keywords: Social Security, Wealth, Intergenerational Transfers, Life-Cycle Saving.

Acknowledgements: I thank Laurence Kotlikoff at Boston University for his comments and Laurence Seidman, J effery Miller, Kenneth Lewis at the University of Delaware for their helpful suggestions. I am grateful to Networks Financial Institute' for its financial support for this study. The views expressed are those of the individual author and do not necessarily reflect official positions of Networks Financial Institute. Please address questions regarding content to Yigit Aydede at aydede@uwindsor.ca. Any errors or omissions are the responsibility of the author.

NFI working papers and other publications are available on NFI's website (www.networksfinancialinstitute.org). Click "Research" and then "Publications/Papers." 


\section{Social Security, Intergenerational Transfers, and Saving: New Evidence from an Emerging Country}

\section{H. Yigit Aydede}

The relationship between saving and social security has been discussed in the literature since Feldstein wrote his influential paper in 1974. Feldstein found that Social Security reduces national saving almost $40 \%$ in the US. Since then, many researchers have been investigating the impact of Social Security on savings in life-cycle, the infinite horizon, and Keynesian models. Because only life-cycle models provide a theoretical justification for the effects of Social Security on national saving, studies ultimately test the strength of this model against other's.

We analyzed the same subject in a time-series setting for Turkey (Aydede 2006a) using the social security wealth series (SSW) calculated for Turkey (Aydede 2006b) between 1970 and 2003. Our time-series study based on the life-cycle model shows that social security wealth, which is the biggest part of household wealth in Turkey, has robust and positive effects on aggregate consumption, and therefore it suppresses aggregate saving. We illustrated the magnitude of this dissaving for the year 2003 by showing that Social Security depresses saving at least $24 \%$ in Turkey - Turkey has one of the most generous social security systems in the OECD region.

Because of several shortcomings of aggregate time-series investigations, cross-section studies outnumber the time-series analyses. ${ }^{1}$ This study is the first of its kind for Turkey that examines the subject in cross-section setting and uses the aggregate social security wealth simulations (Aydede 2006b) to formally analyze whether the pay-as-you-go (PAYG) system in Turkey constitutes intergenerational redistributions of resources. We use the Household Labor Force Survey conducted in 2002 for more than eight thousand households. In this study, instead of applying traditional wealth functions to observe whether social security wealth displaces non-pension wealth, we investigate whether or not households' consumption behavior demonstrates a life-cycle pattern: marginal propensities to consume (MPC) out of total resources should be higher for elderly people relative to young households. If this is the case, despite the absence of a government deficit, any public policy, which redistributes the wealth between generations, decreases national saving. The results confirm that households' MPC declines up to middle age and rises afterwards. Since the Turkish PAYG system involves intergenerational and intertemporal resource transfers we conclude that the current PAYG system may suppress the national saving in Turkey.

The plan for the paper is as follows. Section 1 provides background for our methodology. The Turkish PAYG system and its redistributive features are presented in Section 2. In Section 3, we show the cross-section test results in determining whether MPC follows life-cycle patterns. Section 4 is the conclusion.

\section{Background}

There are three major competing theories in testing whether or not social security or any type of government deficit affects saving: the life-cycle model (Modigliani and Brumberg 1954, Ando and Modigliani 1963, and Modigliani 1986), the infinite-horizon model (Barro

\footnotetext{
${ }^{1}$ See CBO (1998) and Engen and Gale (1997) for a comprehensive summary.
} 
1974), and the Keynesian model. While the first two models are based on rational utilitymaximizing behavior, the Keynesian model does not have micro economic justifications for its arguments. Unlike the infinite-horizon model, in the life-cycle model Ricardian equivalence fails so that the time path of taxes has real impact on economy by changing the severity of tax distortion on different generations. It breaks the link between the horizon of private individuals and that of the government. Since individuals in the life-cycle model have a budget constraint that contains the resources limited by remaining lifetimes, their marginal propensity to consume out of total resources depends on their age. However, in the infinite-horizon model, since the consumption of a household depends not only on its own resources, but rather on total past and future extended family resources, the marginal propensity to consume does not necessarily depend on age. Besides, because mandatory social security transfers between generations are offset by altruistic voluntary transfers, national saving may not be affected by Social Security transfers. Unlike these neoclassical models, which provide a micro-level foundation for aggregate investigations of national saving, the Keynesian model assumes that people care about only today's consumption, and therefore its consumption function has a constant marginal propensity to consume out of income for all ages. Thus, social security wealth predicted in the future does not change today's consumption.

Analyzing the effects of Social Security on consumption and saving requires understanding whether the current social security provisions involve any intertemporal and/or intergenerational resource transfers that affect the present value of lifetime resources in neoclassical models.

Since consumption choices are determined by the optimization of the lifetime resources in infinite-horizon and life-cycle models, any change that does not affect the present value of these resources does not affect individuals' optimization problem and hence consumption schedule. The introduction of Social Security can affect lifetime resources and consumption behavior if it produces lifetime increments or losses (Social Security Wealth - net present value of contributions and benefits based on survival rates) for an individual. Unlike in the PAYG system, social security wealth (SSW) is always zero in a funded social security system as long as the rate of return on contributions is equal to the rate of return on the next best use of the same contributions. Moreover, since every individual's benefit is paid from his own saving pool, a funded system does not reassign available resources between generations.

Understanding how the introduction of a PAYG system can change saving profiles by intertemporal/intergenerational transfers requires further investigation of the relationship between SSW and the reallocation of wealth between generations

Redistribution of Wealth Between Generations: To organize the discussion, we define intergenerational transfers in a very simple, no-uncertainty, no-bequest, and two-period overlapping generations model. We assume that there is no population and productivity growth, real interest rate is constant, people work (earn $w$ and save $s$ ) in the first period and retire and spend their saving in the second period, and the labor supply is exogenous. The only function for the government is to organize the transfers between generations: the young, $y$, gives $t r$ to the old, $o$. With these assumptions, the saving per young at time $t$ can be written as

$$
s_{t}=w_{t}-c_{y t}-t r_{t}
$$

And without liquidity constraints the present value of the budget constraint for the young at time $t$ becomes as follows: 


$$
c_{y t}+\frac{c_{o t+1}}{1+r}=w_{t}+\left(\frac{t r_{t+1}}{1+r}-t r_{t}\right)
$$

How do we define intergenerational transfers in this simple model? Suppose that initially (at time $t$ ) the present value of $t r_{t+1}$ is equal to $t r_{t}$. If this is the case, the budget constraint (2) is not affected by the presence of transfers between generations and the young keeps his consumption path as before. Now consider a different case where the public policy imposes an increase in $t r_{t}$, the amount that the young gives to the old at time $t$, while keeping $t r_{t+1}$ fixed. Unlike the first case, since this policy transfers wealth from the young to the old, the young decreases his consumption at time $t$ due to his declining lifetime resources. What happens to saving at time $t$ ? Because the marginal propensity to consume (MPC) is 1 for the old, the transfer that the old receives at time $t$ is consumed entirely. On the other hand, since the young has an MPC less than unity, this increase in the consumption by the old is not offset by the decrease in $c_{y t}$ by the young. As a result total consumption increases and the saving decreases. We can ask two questions at this point: (1) In the second case above, what if MPC does not follow the pattern in the life-cycle model? (2) What if the public policy transfers resources between generations without changing lifetime resources for the generations but MPC is the same as described in the life-cycle model?

For the first question, if MPC is the same for different cohorts, the increase in consumption by the old can be offset by the decrease in consumption by the young. Therefore, the total consumption remains the same. ${ }^{2}$ For the second question, even if MPC for the old is higher than that of the young, as long as transfers between cohorts are neutral in terms of changing lifetime resources, total consumption do not change. In other words, intergenerational transfers can affect the consumption only if they reallocate wealth between generations with different marginal propensity to consume ${ }^{3}$.

Gift from Unborn Generations: If the government promises to increase $t r_{t+1}$ for the young at time $t$, who ultimately pays for the increase in $t r_{t}$ ? Since the young at time $t+1$ is now able to pass this burden to the next generation, it will be paid by unborn generations. The marginal propensity to consume is zero for unborn generations at time $t$. Therefore, the increase in consumption by the old at time $t$ can not be offset even partially by a decrease in consumption by the young. Consequently, as long as the current generations are able to postpone the payment of this "windfall" to unborn generations, consumption increases and saving declines even more. When it is introduced, if the redistributive public policy promises to each young generation the same wealth increase (or if it is perceived so), not only does the consumption increase at the start-up, but it keeps increasing for each coming generation by cumulating unpaid liabilities for unborn generations.

The introduction of a PAYG system is not different than a public policy that redistributes the wealth between generations. It can change saving profiles by reallocating

\footnotetext{
${ }^{2}$ As long as the policy redistributes the wealth from unborn generations to the current generations it is irrelevant whether or not MPC is different for different cohorts. The MPC for unborn generations is always zero and less than the MPC for the current generations.

${ }^{3}$ Except that there should be an initial point of the policy that a generation receives the transfer (windfall) without any payment (or less than what they received) during their youth. Therefore, if the later transfers are neutral in changing lifetime resources for generations, the total saving should be lower exactly by this windfall. The same argument has been made in the literature by several researchers: Kotlikoff (2001) and Williamson and Jones (1983).
} 
wealth between age cohorts and generations even if it provides no positive or negative SSW, which is neutral in changing lifecycle resources for the current generations. In the introduction of a PAYG system, there is a windfall for the first generation: they are entitled to social security payments in their retirement without paying anything during their youth. Since this windfall, which could be saved by the contemporaneous young, is spent by the old, national saving declines. Any public policy that creates a positive wealth effect (distribution) for the current generations should be considered as if a partial start-up windfall at the cost of forthcoming generations. Therefore, as long as the policy provides that sort of wealth distribution, national saving could be lower than what otherwise would be.

This argument requires further investigation how SSW could behave in a PAYG system. We define a balanced budget for a PAYG system in a simple, no-uncertainty, nobequest, and two-period overlapping generations model as

$$
b_{t+1} R_{t+1}=t r_{t+1} w_{t+1} L_{t+1}
$$

This identity (budget constraint of a PAYG) basically tells us that, in the second period $(t+1)$, total benefits, which is defined as the product of each retiree's benefit, $b$, and the total number of retirees, $R$, should be equal to the total contributions, which is the product of the tax rate, $t r$, the wage, $w$, and the total number of workers, $L$. In order to see the relationship between SSW and the budget constraint of a PAYG system, we can observe this identity for three periods (subscript) and four generations (superscript) as follows:

$$
\begin{aligned}
& b_{t}^{1} R_{t}^{1}=t r_{t}^{2} w_{t}^{2} L_{t}^{2} \\
& b_{t+1}^{2} R_{t+1}^{2}=t r_{t+1}^{3} w_{t+1}^{3} L_{t+1}^{3} \\
& b_{t+2}^{3} R_{t+2}^{3}=t r_{t+2}^{4} w_{t+2}^{4} L_{t+2}^{4}
\end{aligned}
$$

For instance, if the SSW of the second generation is zero as defined below,

$$
b_{t+1}^{2} R_{t+1}^{2}=t r_{t}^{2} w_{t}^{2} L_{t}^{2}\left(1+r_{t}\right),
$$

we can rewrite the budget constraint at the period $t+1$ as follows:

$$
t r_{t+1}^{3} w_{t+1}^{3} L_{t+1}^{3}=t r_{t}^{2} w_{t}^{2} L_{t}^{2}\left(1+r_{t}\right)
$$

which satisfies the following condition:

$$
r_{t}=g_{w}+g_{t r}+g_{L},
$$

where $g$ and $r$ denote growth and interest rates respectively.

If a balanced-budget PAYG system holds the above condition where the interest rate $(r)$ is equal to the internal rate of return (IRR - the right hand side of (7)) of the system, the SSW for the second generation becomes zero. Given this simple example we can observe the following well-known facts in many countries: 
1. Having a trend that $g_{w}$ is almost constant and $g_{L}$ is shrinking ${ }^{4}$, the only way to keep SSW constant at any "promised" level (or "zero") for any generation is to increase $g_{t r}$ for the coming generations.

2. This creates a Ponzi scheme: as long as the trend in demographics persists, every next generation has to pay higher taxes to keep the current generations' wealth constant.

3. Therefore, the unpaid liability or the "legacy debt" grows for unborn generations and creates unsustainable PAYG systems around the world: this debt is $\$ 4.6$ trillion for the next 75 years in the US (Gruber 2006).

4. If the PAYG budget constraint is already broken as in Turkey $^{5}$ and the current generations are not willing to pay the "bill" by increased individual taxes and decreased benefits, public borrowing postpones this "bill" to unborn generations by increasing public debt. Therefore, the zero-SSW condition (7) becomes $r_{t}=g_{w}+g_{t r}+g_{L}+g_{g d}$, where the new term $g_{g d}$ represents the growth rate of the total public debt (and seigniorage tax) due to the PAYG system.

At this point, there should not be any intuitive difference between unpaid liabilities due to a PAYG system and any public debt, for instance, due to an increasing trade deficit: both result in increased consumption (public and private) and decreased national saving today ${ }^{6}$. In other words, since saving is postponed consumption today, every debt is also postponed saving and hence increased consumption today. If generational links are not as altruistic as indicated by the infinite horizon model, every debt created by the current generation translates into higher consumption today and lower consumption (compounded higher saving) for the unborn generations later, even though SSW for the current generations is zero.

As a result, even if the present value of lifetime resources is not affected by the introduction of SSW and therefore individuals' consumption schedule stays the same for the current generations, national saving is lower than what otherwise would be: SSW would have to be negative (or lower) for the current generation if the taxes (or public borrowing) were not increased for the coming generations. In other words, every current generation would have to pay the "bill" by consuming less instead of postponing it to the unborn generations.

However, there are two points that make this result theoretically ambiguous: (1) unlike the life-cycle model, the infinite horizon model claims that Ricardian equivalence holds and altruistic voluntary intergenerational transfers might offset mandatory transfers dictated by the PAYG system (Barro 1974, 1978, and 1989). If this is the case, national saving is not affected. $^{7}$ (2) Since any type of Social Security is basically forced saving, it crowds-out of personal retirement saving. This crowding-out is not necessarily one hundred percent: depending on the relative magnitudes of the substitution and income effects, the introduction of PAYG system might even increase total personal saving, if the exogenous retirement age dictated by the Social Security system is much less than the endogenous retirement age

\footnotetext{
${ }^{4}$ The relative decline in the productive growth has been observed for the last decades in many countries (Steuerle and Bakija (1994)). The increasing longevity and the declining fertility have been causing an aging population around the world. However, populist policies, which regulate the minimum required retirement age in less developed countries without any actuarial base, are also the big reason shrinking $g_{L}$.

${ }^{5}$ The deficit of the PAYG system in Turkey is almost $4.5 \%$ of GDP.

${ }^{6}$ In fact, a decreasing public saving due to a deficit financing of PAYG can create a large trade deficit as in Turkey.

${ }^{7}$ However, there is a common acceptance in the literature that altruistic voluntary transfers are not able to offset the mandatory transfers (Kotlikoff, 2001).
} 
(Feldstein 1974).

For the second point mentioned above, however, if the system is PAYG, which constitutes generational transfers, national saving should still be lower than what it otherwise would be. We can take an extreme example to observe this situation. Suppose that the PAYG system creates a strong incentive for early retirement and therefore increases personal saving. If we assume that the system provides "zero-SSW" conditions for the current generation but not enough to prevent unpaid liabilities for the unborn generations ${ }^{8}$, the current consumption would have still been lower if the system had not redistributed the wealth from younger (or unborn) to older generations. As long as the system represents this wealth redistribution between generations, current consumption would be higher at the cost of decreased consumption for the unborn generations, which translates into a lower national saving in relative terms.

Personal and National Savings: Consider a PAYG system at any point in time whose internal rate of return is equal to the real interest rate and does not create unpaid liabilities for unborn generations. Since the system is neutral in terms of changing lifetime resources, consumption should not change for the young. However, one may think of one more reason for why this redistribution may lead to a decrease in national saving. Since PAYG is not a funded system, contributions made to PAYG by workers directly go to retirees and don not accumulate in a saving pool. Therefore, reductions in workers' personal savings - by contributions - cannot be offset by any type of government saving. ${ }^{9}$ As a result, in our very simple life-cycle setting, national saving falls by contributions as well. ${ }^{10}$

\section{Turkish PAYG System and Its Expected Internal Rate of Return for Cohorts.}

As stated before, understanding whether a public policy that redistributes resources between generations affects national saving requires answers to the following two empirical questions: (1) does the policy reallocate wealth among generations in a way that is not neutral in terms of changing lifetime resources for generations? (2) Do different cohorts have different marginal propensity to consume out of lifetime resources?

In this part, we answer the first question by using the expected present value of Social Security retirement benefits and taxes between 1970 and 2003 for households (Aydede 2006b). Before investigating the magnitude and the time path of intergenerational transfers for different cohorts caused by the Turkish PAYG system, we should review the system first.

The old-age security in Turkey, initiated after the Second World War, consists of three state-managed pension schemes ${ }^{11}$ that pay an earning-related defined benefit financed on a pay-as-you-go basis. In addition to its labor market distortions and redistribution to higher income groups, it is also financially insolvent. The lack of a minimum retirement age, which

\footnotetext{
${ }^{8}$ In other words, without transfers from younger and unborn generations, SSW would be negative for the older generations. With negative SSW, the current generations would consume less than what otherwise would be.

${ }^{9}$ Assuming that PAYG is in balance and the governments' only function is PAYG administration without any cost.

${ }^{10}$ This result can be investigated best by the overlapping generations model. How this reduction occurs in aggregate saving also depends on other factors that may influence saving and whether the internal rate of return for PAYG is different from the market interest rate.

${ }^{11}$ Social Insurance Institution (Sosyal Sigortalar Kurumu - SSK) for wage earners in private and public sectors, Bag-Kur (BK) for self-employed individuals and farmers, and Retirement Fund (Emekli Sandigi - ES) for civil servants
} 
had been removed in 1992, has been the major factor for the financial imbalance-Turkey had retirement ages as young as 47 years of age in SSK (for wage earners) and 48 years of age in ES (for civil servants), the lowest in the world. ${ }^{12}$ Moreover, Turkey is the only country in the world that simultaneously had very low minimum contribution periods (in some cases as low as 10 years) and high replacement rates (90\% in SSK, $127 \%$ in Bag-Kur, and $106 \%$ in ES) ${ }^{13}$ with a lack of minimum retirement age before the 1999 reform (The World Bank Country Economic Memorandum, 2000).

The weak link ${ }^{14}$ between contributions and benefits before 1999 created an incentive for workers to declare the earnings base for paying a premium at a lower value. High informal employment rates due to relatively high statutory contribution rates, the lack of automatic indexation of the contribution ceiling ${ }^{15}$ under high inflation conditions, and the low premium collection rates because of administrative inefficiencies worsened the already financially imbalanced system. As a result, the system became a major fiscal burden, damaging Turkey's macroeconomic stability. Coupled with other structural problems in the economy, the severe financial crisis early in 1999 forced the Turkish government, led by the World Bank, to reform the impaired social security system in August 1999. This "parametric" reform was intended to achieve actuarial balance of the PAYG system in the medium term and to reduce pressure on the borrowing needs of the government.

The most fundamental characteristics of the Turkish social security system have been its generosity (relative to income) due to very young average retirement ages (in some cases 38 for women and 47 for men ${ }^{16}$ ), low minimum contribution periods, and high replacement rates. According to new research by the OECD (2005), a new entrant in Turkey has $\$ 74,000$ average gross pension wealth with $\$ 2,510$ per capita gross national income, compared with $\$ 183,000$ and $\$ 35,430$, respectively, for the US in 2002. In addition, Turkey's gross replacement rate $(87.2 \%)$ is the highest in the OECD region, far above the $56.7 \%$ average. ${ }^{17}$ While this generosity has paved the way for the collapse of the system's actuarial and financial soundness and still presents a big problem for the system's sustainability, one would expect that this generosity would also have strong effects on consumption and saving behaviors of individuals. It is this generosity that makes the Turkish case special relative to other developing countries in the literature.

Legacy Debt: To get the first picture about whether the PAYG system reallocates lifetime resources among generations in Turkey, one only needs to look at the system's significant deficit in terms of GDP. The total deficit financed by public borrowing (and seigniorage) is almost 4.5\% of GDP in 2004. Between 1990 and 2003, the present value of the total resources used to finance the deficit of the social security system is almost equal to the total GNP created by Turkey in 2003. ${ }^{18}$ In other words, the generosity of the system is

\footnotetext{
12 The average minimum retirement ages for OECD countries are 64.4 for men and 63.9 for women in 2002 (OECD 2005).

13 These rates reflects 2004 values and taken from "Proposal for Reform in the Social Security System" (2004).

${ }^{14}$ In SSK, pensions were linked to wages paid in the last five years and the same link was even worse in ES and Bag-Kur: only the last year's wages were used to calculate pensions.

${ }^{15}$ The ceiling on wages subject to social security contribution in the fall of 1995 actually fell below the minimum wage. The World Bank Report (2000, 2003)

${ }^{16}$ See "Turk Emeklilik Sisteminde Reform" (The Reform in Turkish Pension System) TUSIAD November 2004 P.108

${ }^{17}$ Excluding Luxemburg which is an outlier with $101.9 \%$ gross replacement rate.

18 "Proposal for Reform in the Social Security System" (2004), Ministry of Labor and Social Security
} 
financed by unpaid future liabilities, i.e., the increasing legacy debt which does not even include the promises made by the government to unborn generations ${ }^{19}$ : in 32 years the ratio of the population age 65 and over to the total population between 0-64 is expected to increase from $5 \%$ to $14 \%$. The same transition period to reach a 14-percent ratio is 75 years for the US by $2020^{20}$.

The system's generosity and unsustainable financial structure can be seen in the following table (1), which uses the parameters of the system in 1996. The projected deficit for the system in 2005 underestimated the actual by almost $1 \%$ of GDP and that projected for 2010 was realized by 2004 .

Table 1

Main Results of the Actuarial Projections in 1996 by the ILO

$\begin{array}{ccccc}\text { Reverse } & \begin{array}{c}\text { Cumulative } \\ \text { Dependency } \\ \text { Ratio }\end{array} & \begin{array}{c}\text { Replacement } \\ \text { Rate }\end{array} & \begin{array}{c}\text { Deficit } \\ \text { \% of GDP }\end{array} & \begin{array}{c}\text { \% of GDP } \\ \text { Deficit }\end{array} \\ \mathbf{1 9 9 5} & 55 \% & 95 \% & 1.8 \% & 1.8 \% \\ \mathbf{2 0 0 0} & 65 \% & 96 \% & 2.7 \% & 19.7 \% \\ \mathbf{2 0 0 5} & 71 \% & 97 \% & 3.4 \% & 32.1 \% \\ \mathbf{2 0 1 0} & 80 \% & 99 \% & 4.3 \% & 50.2 \% \\ \mathbf{2 0 2 0} & 90 \% & 100 \% & 5.6 \% & 97.3 \% \\ \mathbf{2 0 3 0} & 96 \% & 100 \% & 7.0 \% & 153.9 \% \\ \mathbf{2 0 5 0} & 115 \% & 101 \% & 10.1 \% & 316.0 \%\end{array}$

Sources: "Social security and health insurance reform project, Social Security Final Report", ILO, Geneva, March 1996.

Given the above picture of the social security system, the question at this point should not be whether the PAYG system in Turkey has been and will be redistributive, but the right question should be the one that asks the magnitude and the time path of this redistribution for different generations.

Social Security Wealth: The expected lifetime gains or losses for different generations caused by a PAYG system are calculated in the literature by Social Security Wealth ${ }^{21}$, the difference between the perceived present value of lifetime benefits and taxes based on survival probabilities for households of different genders, age cohorts, and marital circumstances. Social Security Wealth series for Turkey is calculated ${ }^{22}$ for Turkey by Aydede (2006b). In this study we show that anticipated net social security retirement benefits have a value larger than any other financial and non-financial household wealth (including housing) between 1970 and 2003. In simulating the expected present values, we only examine the retirement portion of the system in a partial equilibrium setting in the sense that we do not follow the future effects of the program on labor force participation or personal saving behavior and interest

\footnotetext{
${ }^{19}$ The longevity, 69 years, in 2005 is expected to be 79 years in 2045 in Turkey.

20 "Proposal for Reform in the Social Security System" (2004), Ministry of Labor and Social Security.

${ }^{21}$ It is calculated for the first time by Feldstein $(1974,1976 \mathrm{a}$, and 1976b).

${ }^{22}$ The details of the SSW simulations and the assumptions using the rest-of-the life method can be found in (Aydede 2006b)
} 
rate.

There are two common ways to calculate SSW series: (1) at any given time, SSW series can be calculated for the rest of the lives for all different age cohorts and therefore only future taxes can be taken into the calculation and past taxes could be considered as "sunk"; (2) unlike the first method where SSW increases for older cohorts, it could be calculated at any time as a difference between the present value of incurred and expected lifetime contributions and benefits. Since the emphasis of this paper is to find the average lifetime wealth increments or declines for different generations, we apply the second method here and use SSW series (Aydede 2006b) to find the internal rate of return of the system and the net expected gain and losses for five-year age cohorts.

Intergenerational Transfers and Internal Rate of Return: When a PAYG Social Security is first introduced, it creates a substantial "windfall" for the first retirees of the system. Each time Social Security expands it creates a positive wealth effect for the current generation so it should be considered a partial start-up windfall at the cost of future generations. A "windfall" for a generation does not have to be positive. As explained before, as long as a generation is able to keep its lifetime resources constant (i.e., SSW is zero) by passing some unpaid liabilities to the future generations, they should be considered as receiving a "windfall" at the cost of the reduction in the wealth of future. In fact, this could be the case even with negative SSW for a generation.

Because of aging populations and populist policies, PAYG systems have become unsustainable Ponzi schemes in developing countries and the Turkish social security program is the worst case among them. We analyze the average social security wealth for males ${ }^{23}$ entering the labor market at age 17 for each cohort by calculating the present value of expected benefits to which that he is or will be entitled and contributions that he pays during his entire life. We use three different expectation models (adaptive, rational, and moving average) of future benefits and contributions in a simulation ${ }^{24}$ to translate assumptions about real wages, growth rates of real annuities, mortality rates, and the program's complex rules into expected SSW and internal rates of return (IRR) for cohorts born between 1953 and 1986. These are shown below in Table 2.

\section{Table 2}

Comparison Across Cohorts (with 1987 TL prices for a single male average earner)

$\begin{array}{cccccc}\begin{array}{c}\text { Birth } \\ \text { Years }\end{array} & \begin{array}{c}\text { Year } \\ \text { at 17 }\end{array} & \text { P.V. of Benefits } & \text { P.V. of Taxes } & \text { SSW } & \text { IRR } \\ \mathbf{1 9 5 3} & \mathbf{1 9 7 0} & 3,606,650,457 & 1,825,975,329 & 1,780,675,128 & 98 \% \\ \mathbf{1 9 5 8} & \mathbf{1 9 7 5} & 5,265,707,462 & 3,042,378,077 & 2,223,329,385 & 73 \% \\ \mathbf{1 9 6 3} & \mathbf{1 9 8 0} & 3,048,514,093 & 3,935,052,345 & (886,538,252) & -23 \% \\ \mathbf{1 9 6 8} & \mathbf{1 9 8 5} & 2,577,861,720 & 4,690,226,178 & (2,112,364,458) & -45 \% \\ \mathbf{1 9 7 3} & \mathbf{1 9 9 0} & 3,555,285,563 & 5,078,737,938 & (1,523,452,375) & -30 \% \\ \mathbf{1 9 7 8} & \mathbf{1 9 9 5} & 2,735,679,632 & 4,862,086,157 & (2,126,406,525) & -44 \% \\ \mathbf{1 9 8 3} & \mathbf{2 0 0 0} & 4,695,027,081 & 7,341,357,633 & (2,646,330,552) & -36 \%\end{array}$

${ }^{23}$ The values for females are also calculated. However, since labor force participation rates for females are lower, we present numbers for males as representative individuals of cohorts.

${ }^{24}$ Appendix 1 provides some details about the fundamental functions of the simulation. More details about the simulation can be found in Aydede (2006b). 
$1986^{25} 2003 \quad 5,660,229,224 \quad 4,897,040,346 \quad 763,188,878 \quad 16 \%$

There are several well-known studies that have estimated the expected SSW and internal rate of return for different countries ${ }^{26}$. One common finding of these studies is that the early cohorts received very large rate of returns on their contributions, while later cohorts are likely to have sharply decreasing rate of returns well below the rate of return available on private assets. While our findings are consistent with this literature, the magnitude of the windfall that the earlier retirees ${ }^{27}$ received and the severity of decline in rate of returns for Turkish PAYG are more substantial.

This paper's aim is not to explore the demographic and economic reasons behind this picture in the historical context of the Turkish public policy applications. However, we can safely conclude that Table 2 roughly reveals how significant intergenerational transfers are between cohorts due to the PAYG system. Even though it is not sustainable, as long as the system represents a Ponzi scheme, as indicated in Table 1, every unborn generation will face decreasing SSW.

\section{Marginal Propensity to Consume for Different Age Groups}

As explained before, the reduction in national saving due to intergenerational transfers can be explained by different marginal propensities to consume (MPC) out of lifetime resources for different age cohorts: if MPC out of lifetime resources depends on age, as suggested by the life-cycle theory, people save more (consume less) while they are young and consume more as they get older. Despite the absence of a government deficit, any transfer from young to old, therefore, increases consumption and decreases national saving. While young people have a lower marginal propensity to consume, an increased tax burden from a PAYG system not only reduces total resources of young individuals available for saving, but it also gives them a strong incentive to consume more by entitling them to an unfunded future social security income stream. Likewise, if elderly people have higher marginal propensities to consume, as accepted by the life-cycle model, any increase in their net transfer payments gives them more resources to consume. As a result, any policy, even if it does not create a government deficit, that redistributes the wealth from younger generations to older ones causes national consumption to increase and national saving to fall.

Since two critical points - (1) whether marginal propensities to consume (MPC) out of resources increase by age, and (2) whether altruistic bequests could offset involuntary social security transfers - distinguish the models' predictions on how PAYG affects saving, they have been extensively tested by cross-section studies by looking at whether or not pension wealth displaces non-pension wealth. The major problem with these studies is that they use information on households not on families. In other words, cross-section data do not distinguish transfers across generations from transfers across households. Therefore, any result that shows a negative relationship between pension and non-pension wealth can be consistent with both the infinite-horizon and the life-cycle theories. For example, households with higher social security wealth (SSW) could accumulate less private wealth (non-pension wealth) only

\footnotetext{
${ }^{25}$ The year 2003 is an outlier in terms of the labor force participation rate and the economic growth.

${ }^{26}$ Boskin, Kotlikoff, Puffert, and Shoven (1985); Hurd and Shoven (1985); Boskin, Arvin, and Cone (1983).

${ }^{27}$ Our simulation covers 33 years between 1953 and 1986. However, the Turkish PAYG has started after the Second World War. We are currently working in finding reliable data resource to estimate earlier rates of return of the system between 1945 and 1953. Our first impression is that IRR for the first retirees are even much higher.
} 
because they expect to have a bequest from their parents in the future. Cross-household transfers within an expanded family could make households with greater than average social security wealth accumulate less private wealth than would otherwise be the case. Likewise, a household with higher SSW could have higher non-pension wealth, since its non-pension wealth may include inheritances. Therefore, one could not reach a conclusion simply by looking at a social security wealth coefficient to decide whether or not pension wealth displaces non-pension wealth. ${ }^{28}$

As a result, instead of using a wealth function to observe the coefficient of social security wealth, which needs to be calculated on an individual basis, we choose to apply a traditional life-cycle consumption function to test whether the marginal propensity to consume out of income increases with age. We use a household survey, "Household Labor Force Survey", conducted in 2002 by the State Institute of Statistics (SIS) in Turkey for the crosssection analysis. ${ }^{29}$ The survey has three parts: information on each household's general characteristics, information on each household's consumption, and information on income, demographics and employment status of each individual in each household. Very detailed information on consumption, for example, data on more than 200 different types of consumption expenditures, is the unique characteristic of this household survey; it includes 8,091 households chosen randomly from all parts of Turkey.

To test the argument we discussed above, we use a simple life-cycle model, in which there is no bequest or uncertainty and capital markets are perfect. We take a rational individual who wants to maximize her utility with a given lifetime budget constraint. Let her lifetime utility, $U(t)$, at age $t$ be

$$
U(t)=\sum_{s=t}^{T}(1+\rho)^{t-s} u\left(C_{s}\right)
$$

where $T$ is the age of death and $\rho$ is the personal discount rate. If $C, W, H W$, and $r$ represent consumption, non-human assets, human wealth, and the rate of return on non-human assets respectively, her budget constraint becomes as follows:

\footnotetext{
${ }^{28}$ Auerbach and Kotlikoff state in their influential paper: "Although a social security wealth coefficient would not help resolve the issue, other cross-section regression experiments might help. Under the life-cycle theory, for example, the marginal propensity to consume this period of future resources increases with age. This prediction holds for conventional specification of preferences independent of whether the date of death is taken to be uncertain, and independent of whether annuity insurance is available. In Barro model, the marginal propensity to consume out of total family resources could increase or decrease by age. Hence, given the problem that greater household resources may proxy for greater family resources, the Barro model could not be refuted by a finding that marginal propensity to consume increased by age. But suppose one found that the marginal propensity declined with age. Such a finding would, we believe, be hard to reconcile with the Feldstein life-cycle view. This is an example of a test that could possibly refute the life-cycle theory, but that could not support the strict lifecycle theory over the Barro view. Unfortunately the paucity of U.S. consumption data is not confined to the macro level: there exists no U.S. micro data set that simultaneously reports household consumption and household resources in sufficient detail to conduct the experiment described here. In the absence of micro consumption data, economists have naturally turned to data on net worth and bequest. Net worth partly reflects consumption, but in addition to accumulated past flows of consumption, current net worth reflects accumulated flows of net intergenerational transfers as well as patterns of earnings and rates of return that are not directly related to consumption." (1983, p. 125)

${ }^{29}$ Technical details of the survey can be found in SIS web page: www.die.gov.tr
} 


$$
\sum_{s=t}^{T} C_{s}(1+r)^{t-s} \leq W_{s}+\sum_{s=t}^{T} H W_{s}(1+r)^{t-s}
$$

If we specify the utility function as $u\left(C_{s}\right)=\log C_{s}$ we can derive

$$
C_{s}=\left(\frac{1+r}{1+\rho}\right)^{s-t}\left[\frac{1}{\sum_{s=t}^{T}(1+\rho)^{s-t}}\left[W_{s}+\sum_{s=t}^{T} H W_{s}(1+r)^{t-s}\right]\right]
$$

Equation (10) says that consumption at age $s$ is a function of current and future human and non-human wealth and the marginal propensity to consume out of total resources (in the brackets) increases on the individual's remaining lifetime. Based on Equation (10) we can empirically test the following:

$$
C_{i}=\beta_{0}+\beta_{1} R E_{i}+\beta_{2} P D I_{i}+\beta^{\prime} Z_{i}+u_{i}
$$

where $R E$ and $P D I$ represent the total assets in real estate and personal disposable income (including all forms of government transfers), respectively. $Z$ is a set of dummy variables, which we will define later in the regression analysis. The subscript $i$ stands for each household and $u$ is for the factors that may have effects on consumption but not defined in the function.

In the 2002 survey, an observation about the age pattern of income and consumption behavior is worth mentioning. As seen in the following Figure 1, the average total disposable income (in logs) by the age of households' head shows clear evidence that PDI increases in early ages and falls as the head of the household gets older.

\section{Figure 1: Income - Age}

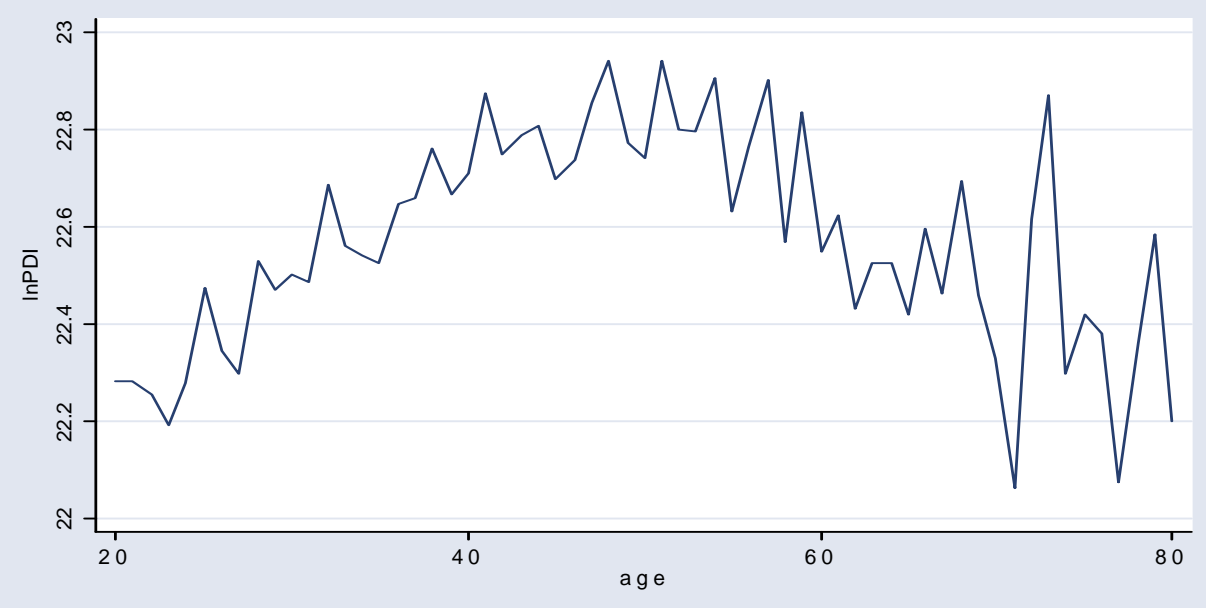

In a simple life-cycle model, because of this hump shaped pattern of income, a rational forward looking person saves when she earns more and dissaves when she earns less to smooth her consumption through her life span. Theoretically, this consumption smoothing, under 
perfect capital market and certainty conditions, should put a horizontal consumption line into the graph above, showing that consumption is independent of age. ${ }^{30}$ However, as evident in Figure 2, the consumption (in logs) pattern is not flat and is similar to the pattern in Figure 1 for income, indicating that consumption expenditures follow the current income very closely.

\section{Figure 2: Consumption - Age}

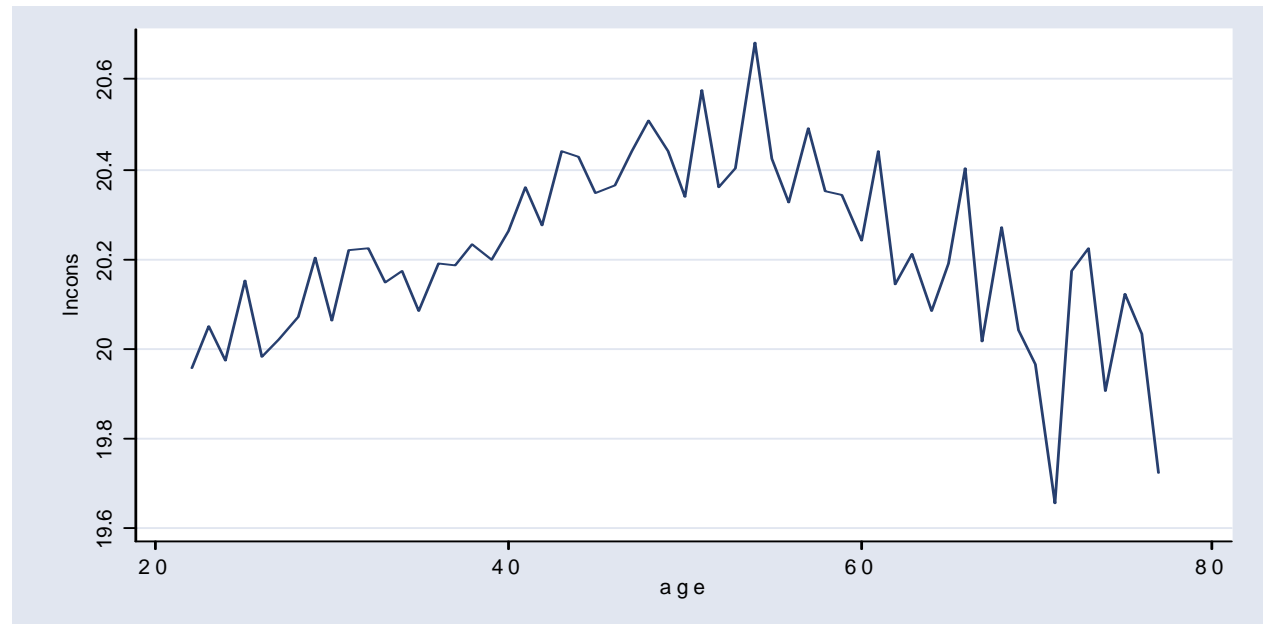

However, this apparent "conflict" between what the data and the life-cycle theory say has a simple explanation: every age group represents a different cohort in our example. Given that every cohort has a different income and consumption structure ${ }^{31}$, the correct comparison of consumption and income patterns should be done within the same cohorts. ${ }^{32}$ This problem can be solved if one compares the marginal propensities to consume out of total resources for different age groups.

\section{Regression Results}

In order to analyze whether $\beta_{2}$ in equation (11) presents an age pattern similar to the one that the life-cycle model suggests, we construct nine age dummies as follows:

DAge $=1$ if Age $<25$, otherwise 0

DAge $1=1$ if $25=<$ Age $<30$, otherwise 0 ;

DAge $2=1$ if $30=<$ Age $<35$, otherwise 0 ;

DAge $3=1$ if $35=<$ Age $<40$, otherwise 0 ;

DAge $4=1$ if $40=<$ Age $<45$, otherwise 0

DAge $5=1$ if $45=<$ Age $<50$, otherwise 0

DAge $6=1$ if $50=<$ Age $<55$, otherwise 0 ;

DAge $7=1$ if $55=<$ Age $<60$, otherwise 0 ;

\footnotetext{
${ }^{30}$ If we further assume that the marginal utility is constant.

${ }^{31}$ Due to economic progress, elderly people may have a lower level of income relative to younger population; therefore, consumption and income both might decline as age increases.

32 This kind of study needs a time-series cross-section data set. A similar study is done by Axel Borsch-Supan (2003).
} 
DAge $8=1$ if $60=<$ Age $<65$, otherwise 0

DAge $9=1$ if $65=<$ Age, otherwise 0;

where "Age" represents the age of each household head. In addition to these age dummies, we use the following set of dummy variables that might influence the consumption behavior of a household.

$E d u=1$, if HHH's education is higher than elementary school, 0 otherwise;

Indebt $=1$, if $\mathrm{HH}$ has a financial debt, 0 otherwise;

$E m \quad=1$, if $\mathrm{HHH}$ is employed, 0 otherwise;

$F A=1$, if $\mathrm{HH}$ has financial assets, 0 otherwise;

sex $=1$, if $\mathrm{HHH}$ is male, 0 otherwise;

Car $=1$, if $\mathrm{HH}$ has a car, 0 otherwise;

$S S=1$, if $\mathrm{HHH}$ is in the public social security system, 0 otherwise;

where $\mathrm{HH}$ and $\mathrm{HHH}$ represent household and household head respectively. Moreover, we add four additional variables into equation (11): $N$, the number of individuals in a household; $R E$, the total real estate wealth that a household has; Life, the total premium that a household pays for a private life insurance; and ratio, the ratio of monthly total disposable income (at the time that survey was conducted) to the yearly income. Since the consumption data in the surveys is given monthly, we use the last variable, ratio, to control the effect of extraordinary differences between the current month's income and the average monthly income on consumption.

Before presenting the regression results, there are two points that should be mentioned: first, since we investigate short-term consumption behavior, we take total consumption expenditure on non-durable goods and services as the dependent variable by removing spending on cars, durable housing goods, jewelry, and private life insurance from the total. Secondly, in order to reduce the effect of outliers in the 2002 data, we eliminate 223 households whose total yearly disposable income is seven times below or above the average $(7,230,000,000 \mathrm{TL})$. After this truncation, we have 7,868 households in the 2002 survey as shown below:

\section{Age Groups}

Number of Households

DAge0:

DAge1:

DAge2:

DAge3:

DAge4:

DAge5:

DAge6:

DAge7:

DAge8:

DAge9:

Total Number of Households:
144

687

1.042

1,183

1,122

1,018

870

566

453

783

7,868 
A part of the regression results (from STATA 8.0) are given in Table 1 below. The entire results can be found in the Appendix 2. Negative numbers are in parentheses and the dependent variable is total expenditures on non-durable goods and services as defined above. Figure 3: Regression with Robust Standard Errors

$\begin{array}{lc}\text { Number of Observation } & 7,868 \\ \text { R-squared } & 0.8585 \\ \text { Root MSE } & 270,000,000\end{array}$

$\begin{array}{lcccc}\text { Variables } & \text { Coefficients } & \begin{array}{c}\text { Robust } \\ \text { Std. Errors }\end{array} & \mathbf{t} & \mathbf{P}>\mathbf{t} \\ \text { DAge0ainc } & 0.59933 & 0.09956 & 6.02 & 0.00000 \\ \text { DAge1ainc } & 0.50075 & 0.06644 & 7.54 & 0.00000 \\ \text { DAge2ainc } & 0.50174 & 0.04265 & 11.76 & 0.00000 \\ \text { DAge3ainc } & 0.42035 & 0.05721 & 7.35 & 0.00000 \\ \text { DAge4ainc } & 0.35518 & 0.06097 & 5.83 & 0.00000 \\ \text { DAge5ainc } & 0.40677 & 0.05096 & 7.98 & 0.00000 \\ \text { DAge6ainc } & 0.44749 & 0.06501 & 6.88 & 0.00000 \\ \text { DAge7ainc } & 0.53663 & 0.04749 & 11.30 & 0.00000 \\ \text { DAge8ainc } & 0.61050 & 0.06573 & 9.29 & 0.00000 \\ \text { DAge9ainc } & 0.48305 & 0.05883 & 8.21 & 0.00000\end{array}$

As indicated in Figure 3, we used robust standard errors ${ }^{33}$ in order to solve the heteroskedasticity problem, which is a very common setback particularly in analyses using cross-section data. Moreover, since all nine age dummies are used, we suppress the constant in the regression.

The first thing to observe is that the coefficients of monthly disposable income for each age group (denoted by ainc) are statistically significant and present a pattern that seems consistent with the life-cycle theory as shown in Figure 4 below.

Figure 4: Marginal Propensities to Consume (MPC)

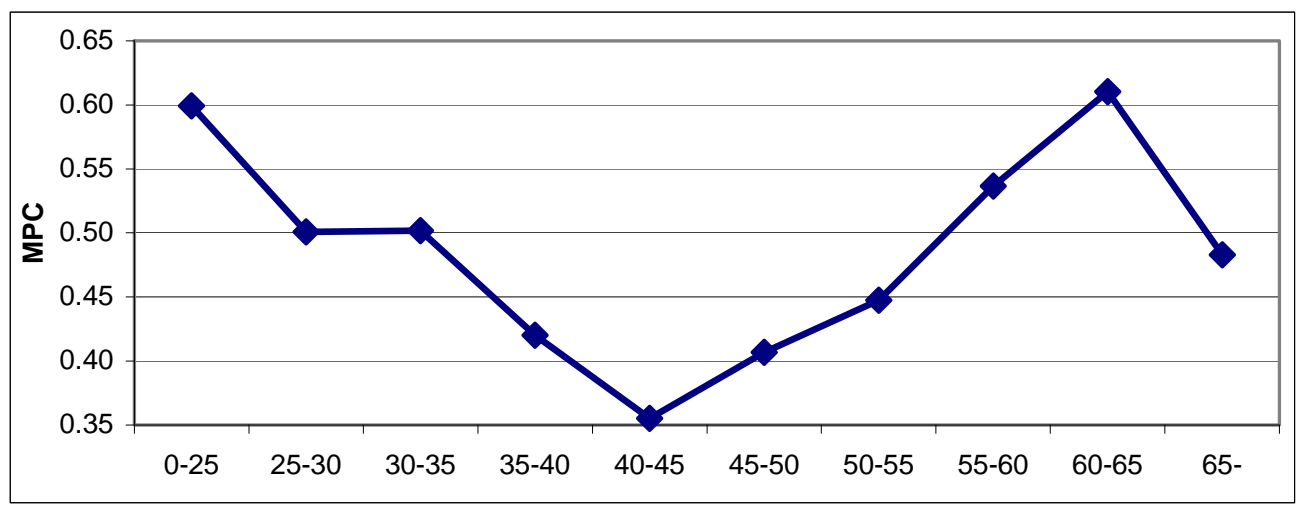

Nevertheless, the last age group, 65 and older, has a decreasing marginal propensity to

\footnotetext{
${ }^{33}$ Here we use a special feature of STATA 8.0 that calculates White's heteroskedasticity-corrected standard errors.
} 
consume out of income (MPC). In a developing country with a traditional family structure, if an older parent lives with his/her mid-age children, he (or she) may be shown as a head of the household, as in the survey, although he (or she) is not the principal income earner. The data indicates that 232 of 783 household heads in this group are single (because her/his partner is deceased) and live with their children, and that $80 \%$ of them are female.

In order to understand whether or not the apparent age pattern of MPC is statistically significant, we run a simple regression, where TIME starts from 1 (for the first age group) to 10 and TIMESQR is the square of TIME. As seen in the following Figure 5, the results confirm the shape of MPC in Figure 4.

\section{Figure 5: Age Trend of MPC - OLS Regression}

Dependent Variable: MPC

Method: Least Squares

Included observations: 10

$\begin{array}{lllll}\text { Variable } & \text { Coefficient } & \text { Std. Error } & \text { t-Statistic } & \text { Prob. } \\ \text { Constant } & \mathbf{0 . 6 5 4 1 3} & 0.07627 & 8.57698 & 0.00010 \\ \text { TIME } & \mathbf{( 0 . 0 8 4 2 9 )} & 0.03185 & (2.64621) & 0.03310 \\ \text { TIMESQR } & \mathbf{0 . 0 0 7 6 8} & 0.00282 & 2.72100 & 0.02970 \\ & & & \\ \text { R-squared } & 0.514039 & \text { Durbin-Watson stat } & 1.761629 \\ \text { S.E. of regression } & 0.064844 & & \\ \text { Sum squared residuals } & 0.029433 & & \end{array}$

In addition to the fact that the age pattern of MPC is consistent with life-cycle theory, the data also give some important information about the factors represented by other variables. The coefficients of ratio are significant for the mid-age groups (from DAge3 to Dage7) and have the expected signs for each age group (except for the first age group). This result is consistent with the life-cycle theory, indicating that any temporary increase in income may not be spent but saved by rational individuals to smooth consumption through their lifetime.

The regression results show that higher education is indicative of higher spending. In each age group, the higher education, middle school and above, provides higher consumption opportunities. Interestingly, the employment status of a household's head does not strongly affect consumption. In fact, the sign of the coefficients contradicts the commonsense notion that an employed person should have better sources to consume. However, when we look more closely at the results, we can observe that, even they are not significant, the negative signs belong to old and young age groups (except for DAge4). This can be explained by the fact that retired people may have better economic resources than employed people, given that the minimum retirement age can be as low as 34 in Turkey.

The total number of individuals in a household $(N)$, having a private life insurance, debt, or financial assets (life, Indebt, FA), and household head's sex (sex) do not affect consumption behavior significantly for given age groups. However, if a household has a car (Car), the regression results show that it has relatively higher consumption spending. The other interesting result is that mid-age households whose heads are covered by one of the three public social security systems have a higher level of consumption. Although not significant, this observation is exactly opposite for the older age groups, indicating that people without any 
type of public social security have higher consumption spending levels than people who have social security coverage. This fact may explain that people at older ages without public social security coverage should work to cover their expenses and therefore may have relatively better resources than retirees.

\section{Conclusion}

There are two common types of empirical research in the literature that investigates the relationship between saving and Social Security: time-series and cross-section studies. Even though only time series studies are able to quantify the magnitude of the reduction (if one exists) for the aggregate economy, they have serious drawbacks. ${ }^{34}$ Nevertheless, as shown by Auerbach and Kotlikoff (1983), the cross-section studies are not immune from problems either: as commonly used in the literature, the coefficients of the social security wealth variable in traditional individual wealth functions are not able to settle the argument between the Feldstein and Barro views. However, if the wealth distribution is significant between different age cohorts as well as between generations, a different marginal propensity to consume for different age cohorts promises a decline in national saving. Therefore, instead of analyzing whether the PAYG system leads substitution effects between pension and non-pension wealth, we investigate whether the system represents a Ponzi scheme and leads to significant wealth transfers between different age cohorts with marginal propensities to consume that follow a life-cycle pattern. We argue that if this is the case, national saving should be less than what otherwise would be.

Turkey is a unique case in this literature: it has the most generous and redistributive social security system in the OECD region. This study is the first analysis that formally shows the magnitude of the intergenerational transfers for Turkey. The results reveal several important points: (1) the "windfall" for the earlier generations is very substantial; (2) even though the current generations have negative social security wealth, the system represents an unsustainable Ponzi scheme and transfers significant wealth from unborn generations to the current generations; (3) There are substantial wealth transfers among different age cohorts of the current generations born between 1953 and 1986.

If the system represents a Ponzi scheme and transfers wealth among different age cohorts as in Turkey, the fact that the marginal propensity to consume that is significantly different for different age cohorts should lead to a decline in national saving. We use the 2002 survey in this cross-section analysis to test whether the MPC follows a life-cycle pattern in Turkey. The results confirm the prediction of the life-cycle theory about the age pattern of the marginal propensity to consume (MPC): the MPC first decreases and then increases by age.

The two results, substantial wealth transfers between generations and different marginal propensities to consume for different age cohorts, provide new evidence that the PAYG system in Turkey suppresses national saving.

\footnotetext{
${ }^{34}$ See Seidman (1985 and 1999).
} 


\section{Appendix 1: Definitions for P.V. of Benefits (SSWG) and Contribution (SSTX)}

(1) $S S W G_{t}=\sum_{a=15}^{r a}\left(W_{a, t} / P_{a, t}\right)^{G} C_{t}^{G} b f_{t}^{G} Y_{t} S_{(a, r a)}^{G}[(1+g) /(1+d)]^{(r a-a)} \sum_{n=r a}^{85} S_{(r a, n)}^{G}[(1+g a) /(1+d)]^{(n-r a)}$

(2) $\operatorname{SSTX} X_{t}=\sum_{a=15}^{r a}\left(W_{a, t} / P_{a, t}\right)^{G} C_{t}^{G} \theta_{t}^{G} Y_{t} \sum_{m=a}^{r a} S_{a, m}^{G}[(1+g) /(1+d)]^{m-a}$

$M=$ Male, $F=$ Female, $G=$ Gender $t=$ year, $a=$ age at time $t, r a=$ retirement age, ara = average age for retirees, $m=$ age between current age $a$ and retirement age ra, $n=$ age between retirement age ra and the maximum age, 85, w= wives, $O=$ orphans, $d$ = personal discount rate, $g=$ growth rate of real reference income, $g a=$ growth rate of real annuities, $W=$ number of employers, $P=L F P R$ adjustment factor, $C=$ ratio of active insured employment to total employment, $\theta=$ tax factor, $Y=$ reference income, $A V B=$ per retiree average old-age benefit, $A B D=$ per retiree average disability benefit, $A B S W=$ per retiree (wives) average survivors benefit, $A B S O=$ per retiree (orphans) average survivors benefit $S_{(a, m)}=$ survival probability of a person who lives up to age $m$, given that she/he lived up to age a, bf = benefit factor, $N=$ number of old-age beneficiaries, $s r=\%$ of male married, BR = discount ratio for benefits passed from worker or retirees to survivors.

\section{Benefits (Future Annuities -- SSWG):}

- If an individual at the age of $(a)$ in year $(t)$ survives to age $r a$, and if his current real disposable income, $Y_{(a, t)}$, grows at a constant rate of growth, $g$, then he'll have a disposable income at the age of $r a: Y_{t+r a-a}=Y_{t}(1+g)^{(r a-a)}$

- In order to find the first annual social security benefit at $r a$ for that particular individual, we look at the past data and come up with a benefit factor, $b f$, which is basically a ratio of per retiree annual old-age benefits to per capita NPrvDI.

- Given that factor, the individual will be entitled to his first annual social security benefit at age $r a$, which is $B_{(a, t)}=b f_{t} Y_{t}(1+g)^{(r a-a)}$.

- We assume that real annuities grow after $r a$ by ga until the truncated maximum age of 85.

- Given the survival probabilities $S_{i, j}$ for that particular individual, the actuarial present value can be calculated at the age of $r a$, where $S_{i, j}$ presents the probability of living at least up to the age of $j$, given that the person lived to age $i$.

- With the personal discount rate $(d)$ for future real incomes, the present value of future benefits can be written as (1) above.

\section{Taxes (future social security tax liabilities - SSTX):}

- If the same individual at the age of $(a)$ in year $(t)$ survives to age $r a$, and if his current real disposable income, $Y_{(a, t)}$, grows at a constant rate of growth, $g$, then the present value of all his future taxes until age $r a$ is

$T A X_{a, t}=\sum_{m=a}^{r a} S_{a, m} \theta_{t+m-a} Y_{t}[(1+g) /(1+d)]^{m-a}$, where $\theta$ is the ratio of social security taxes (Old-age, disability and survival - ODS) per worker to per capita disposable income and the person expects that at the age $m$ he will pay a tax of $T_{t+m-a}=\theta_{t+m-a} Y_{t}(1+g)^{m-a}$. The final expression for the present value of expected contribution can be written as (2) above. 
Appendix2: Regression Results

Number of Observation

R-squared

Root MSE

Variables

DAge0

DAge1

DAge2

DAge3

DAge4

DAge5

DAge6

DAge7

DAge8

DAge9

DAge0ainc

DAge1ainc

DAge2ainc

DAge3ainc

DAge4ainc

DAge5ainc

DAge6ainc

DAge7ainc

DAge8ainc

DAge9ainc

DAge0ratio

DAge1 ratio

DAge2ratio

DAge3ratio

DAge4ratio

DAge5ratio

DAge6ratio

DAge7ratio

DAge8ratio

DAge9ratio

DAge0RE

DAge1RE

DAge2RE

DAge3RE

DAge4RE

DAge5RE

DAge6RE

DAge7RE
7,868

0.8585

270,000,000
Robust

Coefficients
$1.58 \mathrm{E}+08$
$1.45 \mathrm{E}+08$
$2.34 \mathrm{E}+08$
$3.07 \mathrm{E}+08$
$3.74 \mathrm{E}+08$
$4.13 \mathrm{E}+08$
$2.93 \mathrm{E}+08$
$2.63 \mathrm{E}+08$
$2.11 \mathrm{E}+08$
$2.11 \mathrm{E}+08$
$\mathbf{0 . 5 9 9 3 3}$

0.50075

0.50174

0.42035

0.35518

0.40677

0.44749

0.53663

0.61050

0.48305

$1.76 \mathrm{E}+08$

$-1.61 \mathrm{E}+08$

$-7.06 \mathrm{E}+08$

$-7.24 \mathrm{E}+08$

$-6.30 \mathrm{E}+08$

$-1.95 \mathrm{E}+09$

$-7.33 \mathrm{E}+08$

$-8.56 \mathrm{E}+08$

$-5.46 \mathrm{E}+08$

$-2.02 \mathrm{E}+08$

0.000381

0.000650

0.000327

0.000126

0.000467

0.000182

0.000016

(0.000127)
Std. Errors

$6.37 \mathrm{E}+07$

$5.95 \mathrm{E}+07$

$4.12 \mathrm{E}+07$

$4.80 \mathrm{E}+07$

$5.03 \mathrm{E}+07$

$6.27 \mathrm{E}+07$

$4.20 \mathrm{E}+07$

$5.87 \mathrm{E}+07$

$4.40 \mathrm{E}+07$

$4.67 \mathrm{E}+07$

0.09956

$\mathbf{0 . 0 6 6 4 4}$

0.04265

0.05721

0.06097

0.05096

0.06501

0.04749

0.06573

$\mathbf{0 . 0 5 8 8 3}$

4. $22 \mathrm{E}+08$

$3.50 \mathrm{E}+08$

$2.03 \mathrm{E}+08$

$2.15 \mathrm{E}+08$

$2.69 \mathrm{E}+08$

$4.90 \mathrm{E}+08$

$3.23 \mathrm{E}+08$

$4.62 \mathrm{E}+08$

$3.90 \mathrm{E}+08$

$4.51 \mathrm{E}+08$

0.000458

0.000334

0.000170

0.000113

0.000086

0.000082

0.000091

0.000109 t $\quad \mathbf{P}>\mathbf{t}$

$2.48 \quad 0.01300$

$2.43 \quad 0.01500$

$5.68 \quad 0.00000$

$\begin{array}{ll}6.39 & 0.00000\end{array}$

$\begin{array}{ll}7.42 & 0.00000\end{array}$

$\begin{array}{ll}6.58 & 0.00000\end{array}$

$\begin{array}{ll}6.97 & 0.00000\end{array}$

$4.48 \quad 0.00000$

$4.79 \quad 0.00000$

$4.51 \quad 0.00000$

6.020 .00000

$\begin{array}{ll}7.54 & 0.00000\end{array}$

11.760 .00000

$\begin{array}{ll}7.35 & \mathbf{0 . 0 0 0 0 0}\end{array}$

$\begin{array}{ll}5.83 & 0.00000\end{array}$

$\begin{array}{ll}7.98 & 0.00000\end{array}$

$6.88 \quad 0.00000$

$11.30 \quad 0.00000$

$9.29 \quad 0.00000$

8.210 .00000

$0.42 \quad 0.67700$

(0.46) $\quad 0.64500$

(3.48) $\quad 0.00100$

(3.37) $\quad 0.00100$

(2.34) $\quad 0.01900$

(3.98) $\quad 0.00000$

(2.27) $\quad 0.02300$

(1.85) $\quad 0.06400$

(1.40) $\quad 0.16200$

(0.45) $\quad 0.65400$

$0.83 \quad 0.40500$

$1.95 \quad 0.05100$

$1.93 \quad 0.05400$

$1.12 \quad 0.26500$

$5.42 \quad 0.00000$

$2.22 \quad 0.02700$

$0.18 \quad 0.85900$

(1.16) $\quad 0.24400$ 


\begin{tabular}{|c|c|c|c|c|}
\hline DAge8RE & $(0.000008)$ & 0.000151 & $(0.05)$ & 0.95700 \\
\hline DAge9RE & 0.000033 & 0.000064 & 0.51 & 0.61100 \\
\hline DAge0life & 1.16167 & 2.62998 & 0.44 & 0.65900 \\
\hline DAge1life & 2.06758 & 3.35311 & 0.62 & 0.53800 \\
\hline DAge2life & 2.75183 & 1.33582 & 2.06 & 0.03900 \\
\hline DAge3life & 0.19380 & 0.61664 & 0.31 & 0.75300 \\
\hline DAge4life & 0.27787 & 0.79588 & 0.35 & 0.72700 \\
\hline DAge5life & 0.14290 & 0.43541 & 0.33 & 0.74300 \\
\hline DAge6life & $(0.30883)$ & 1.43377 & $(0.22)$ & 0.82900 \\
\hline DAge7life & $(1.04373)$ & 3.07187 & $(0.34)$ & 0.73400 \\
\hline DAge8life & 1.68434 & 0.87687 & 1.92 & 0.05500 \\
\hline DAge9life & 2.35951 & 1.08208 & 2.18 & 0.02900 \\
\hline DAge0N & $-1.62 \mathrm{E}+07$ & $1.58 \mathrm{E}+07$ & $(1.03)$ & 0.30300 \\
\hline DAge1N & 8080799 & 7901417 & 1.02 & 0.30600 \\
\hline DAge2N & 3598767 & 6183962 & 0.58 & 0.56100 \\
\hline DAge3N & 2214269 & 4769511 & 0.46 & 0.64200 \\
\hline DAge4N & 765768 & 4870610 & 0.16 & 0.87500 \\
\hline DAge 5N & $1.10 \mathrm{E}+07$ & 5413075 & 2.03 & 0.04200 \\
\hline DAge6N & 4420347 & 5363132 & 0.82 & 0.41000 \\
\hline DAge $7 \mathrm{~N}$ & $1.04 \mathrm{E}+07$ & 6516803 & 1.60 & 0.10900 \\
\hline DAge8N & 6050933 & 8288202 & 0.73 & 0.46500 \\
\hline DAge9N & $1.56 \mathrm{E}+07$ & 5013506 & 3.11 & 0.00200 \\
\hline DAge0Edu & $1.24 \mathrm{E}+07$ & $3.64 \mathrm{E}+07$ & 0.34 & 0.73300 \\
\hline DAge1Edu & $6.41 \mathrm{E}+07$ & $1.77 \mathrm{E}+07$ & 3.62 & 0.00000 \\
\hline DAge2Edu & $4.00 \mathrm{E}+07$ & $1.37 \mathrm{E}+07$ & 2.91 & 0.00400 \\
\hline DAge3Edu & $5.03 \mathrm{E}+07$ & $1.77 \mathrm{E}+07$ & 2.84 & 0.00500 \\
\hline DAge4Edu & $7.87 \mathrm{E}+07$ & $1.94 \mathrm{E}+07$ & 4.06 & 0.00000 \\
\hline DAge5Edu & $9.82 \mathrm{E}+07$ & $2.35 \mathrm{E}+07$ & 4.19 & 0.00000 \\
\hline DAge6Edu & $1.39 \mathrm{E}+08$ & $2.74 \mathrm{E}+07$ & 5.08 & 0.00000 \\
\hline DAge7Edu & $1.54 \mathrm{E}+08$ & $4.07 \mathrm{E}+07$ & 3.79 & 0.00000 \\
\hline DAge8Edu & $1.05 \mathrm{E}+08$ & $3.51 \mathrm{E}+07$ & 2.99 & 0.00300 \\
\hline DAge9Edu & $1.67 \mathrm{E}+08$ & $2.91 \mathrm{E}+07$ & 5.76 & 0.00000 \\
\hline DAge0Em & $-7.35 \mathrm{E}+07$ & $5.63 \mathrm{E}+07$ & $(1.31)$ & 0.19100 \\
\hline DAge1Em & -857836.8 & $3.27 \mathrm{E}+07$ & $(0.03)$ & 0.97900 \\
\hline DAge2Em & $2.49 \mathrm{E}+07$ & $2.56 \mathrm{E}+07$ & 0.97 & 0.33200 \\
\hline DAge3Em & $1.29 \mathrm{E}+07$ & $2.46 \mathrm{E}+07$ & 0.52 & 0.60000 \\
\hline DAge4Em & $-4.99 \mathrm{E}+07$ & $2.88 \mathrm{E}+07$ & $(1.73)$ & 0.08400 \\
\hline DAge5Em & 6007207 & $2.32 \mathrm{E}+07$ & 0.26 & 0.79500 \\
\hline DAge6Em & $-1.73 \mathrm{E}+07$ & $2.55 \mathrm{E}+07$ & $(0.68)$ & 0.49700 \\
\hline DAge7Em & $-4.24 \mathrm{E}+07$ & $3.31 \mathrm{E}+07$ & $(1.28)$ & 0.20000 \\
\hline DAge8Em & $-5.27 \mathrm{E}+07$ & $2.93 \mathrm{E}+07$ & $(1.80)$ & 0.07300 \\
\hline DAge9Em & $-1.52 \mathrm{E}+07$ & $3.28 \mathrm{E}+07$ & $(0.46)$ & 0.64300 \\
\hline DAge0Indebt & -6670472 & $3.20 \mathrm{E}+07$ & $(0.21)$ & 0.83500 \\
\hline DAge1Indebt & $2.37 \mathrm{E}+07$ & $1.88 \mathrm{E}+07$ & 1.26 & 0.20600 \\
\hline DAge2Indebt & 1540660 & $1.57 \mathrm{E}+07$ & 0.10 & 0.92200 \\
\hline DAge3Indebt & 6084679 & $1.47 \mathrm{E}+07$ & 0.41 & 0.67900 \\
\hline
\end{tabular}




DAge4Indebt
DAge5Indebt
DAge6Indebt
DAge7Indebt
DAge8Indebt
DAge9Indebt
DAge0FA
DAge1FA
DAge2FA
DAge3FA
DAge4FA
DAge5FA
DAge6FA
DAge7FA
DAge8FA
DAge9FA
DAge0sex
DAge1sex
DAge2sex
DAge3sex
DAge4sex
DAge5sex
DAge7SS
DAge8SS
DAge9SS
DAge6sex
DAge7sex
DAge8sex
DAge9sex
DAge3SS
DAgeCar
DAge1Car
DAge2Car
DAge0SS
DAge3Car
DAge4Car
DAge5Car
DAge6Car
DAge7Car
DAge8Car
DAge9Car
DAge
DAge

$\begin{array}{cccc}3824812 & 1.84 \mathrm{E}+07 & 0.21 & 0.83500 \\ 4.01 \mathrm{E}+07 & 2.00 \mathrm{E}+07 & 2.00 & 0.04600 \\ 4.36 \mathrm{E}+07 & 2.29 \mathrm{E}+07 & 1.90 & 0.05700 \\ 5.77 \mathrm{E}+07 & 2.37 \mathrm{E}+07 & 2.43 & 0.01500 \\ 2.83 \mathrm{E}+07 & 2.59 \mathrm{E}+07 & 1.09 & 0.27400 \\ 2.41 \mathrm{E}+07 & 1.85 \mathrm{E}+07 & 1.31 & 0.19100 \\ -1.27 \mathrm{E}+08 & 9.73 \mathrm{E}+07 & (1.30) & 0.19300 \\ -4.08 \mathrm{E}+07 & 6.23 \mathrm{E}+07 & (0.66) & 0.51200 \\ -1799373 & 6.98 \mathrm{E}+07 & (0.03) & 0.97900 \\ 774460.5 & 4.18 \mathrm{E}+07 & 0.02 & 0.98500 \\ -2.62 \mathrm{E}+07 & 4.08 \mathrm{E}+07 & (0.64) & 0.52000 \\ 7.41 \mathrm{E}+07 & 4.07 \mathrm{E}+07 & 1.82 & 0.06900 \\ 1.78 \mathrm{E}+07 & 6.33 \mathrm{E}+07 & 0.28 & 0.77900 \\ -9.13 \mathrm{E}+07 & 4.94 \mathrm{E}+07 & (1.85) & 0.06400 \\ 2.95 \mathrm{E}+07 & 6.00 \mathrm{E}+07 & 0.49 & 0.62300 \\ -1.83 \mathrm{E}+07 & 4.58 \mathrm{E}+07 & (0.40) & 0.68900 \\ 9.62 \mathrm{E}+07 & 4.03 \mathrm{E}+07 & 2.39 & 0.01700 \\ -5.58 \mathrm{E}+07 & 4.31 \mathrm{E}+07 & (1.30) & 0.19500 \\ -2.26 \mathrm{E}+07 & 3.67 \mathrm{E}+07 & (0.62) & 0.53800 \\ -5.94 \mathrm{E}+07 & 3.82 \mathrm{E}+07 & (1.55) & 0.12000 \\ -3.46 \mathrm{E}+07 & 3.56 \mathrm{E}+07 & (0.97) & 0.33200 \\ -4.10 \mathrm{E}+07 & 3.52 \mathrm{E}+07 & (1.16) & 0.24400 \\ 1.58 \mathrm{E}+07 & 2.73 \mathrm{E}+07 & 0.58 & 0.56300 \\ 1.35 \mathrm{E}+07 & 3.60 \mathrm{E}+07 & 0.37 & 0.70900 \\ 3.29 \mathrm{E}+07 & 2.87 \mathrm{E}+07 & 1.15 & 0.25100 \\ -3.22 \mathrm{E}+07 & 2.13 \mathrm{E}+07 & (1.51) & 0.13000 \\ 1.01 \mathrm{E}+07 & 7.24 \mathrm{E}+07 & 0.14 & 0.88900 \\ 8.69 \mathrm{E}+07 & 4.07 \mathrm{E}+07 & 2.14 & 0.03300 \\ 3.42 \mathrm{E}+07 & 2.16 \mathrm{E}+07 & 1.58 & 0.11300 \\ 1.10 \mathrm{E}+08 & 2.30 \mathrm{E}+07 & 4.77 & 0.00000 \\ 8.73 \mathrm{E}+07 & 2.35 \mathrm{E}+07 & 3.72 & 0.00000 \\ 1.11 \mathrm{E}+08 & 2.80 \mathrm{E}+07 & 3.95 & 0.00000 \\ 9.62 \mathrm{E}+07 & 2.54 \mathrm{E}+07 & 3.78 & 0.00000 \\ 8.76 \mathrm{E}+07 & 3.97 \mathrm{E}+07 & 2.21 & 0.02700 \\ 6.19 \mathrm{E}+07 & 4.34 \mathrm{E}+07 & 1.43 & 0.15400 \\ 1.30 \mathrm{E}+08 & 4.56 \mathrm{E}+07 & 2.85 & 0.00400 \\ 1.60 \mathrm{E}+07 & 4.38 \mathrm{E}+07 & 0.37 & 0.71500 \\ 6.94 \mathrm{E}+07 & 1.76 \mathrm{E}+07 & 3.95 & 0.00000 \\ 1.59 \mathrm{E}+07 & 1.87 \mathrm{E}+07 & 0.85 & 0.39400 \\ 4.37 \mathrm{E}+07 & 1.37 \mathrm{E}+07 & 3.18 & 0.00100 \\ 4.11 \mathrm{E}+07 & 1.96 \mathrm{E}+07 & 2.09 & 0.03700 \\ 5.61 \mathrm{E}+07 & 2.50 \mathrm{E}+07 & 2.24 & 0.02500 \\ -1.85 \mathrm{E}+07 & 3.29 \mathrm{E}+07 & (0.56) & 0.57400 \\ -2.04 \mathrm{E}+07 & 4.46 \mathrm{E}+07 & (0.46) & 0.64800 \\ -1.45 \mathrm{E}+08 & 6.44 \mathrm{E}+07 & (2.25) & 0.02400 \\ -7.63 \mathrm{E}+07 & 6.61 \mathrm{E}+07 & (1.15) & 0.24900\end{array}$




\section{References:}

Ando, A. and Modigliani, F. (1963). The Life Cycle Hypothesis of Saving: Aggregate Implications and Tests, The American Economic Review, Vol.53.

Aydede (2006a). Aggregate Consumption Function and Public Social Security: The First Time-Series Study for a Developing Country, Turkey, Applied Economics. Forthcoming

Aydede (2006b). Social Security Wealth Simulations: Expected Intergenerational Redistribution and Internal Rate of Return Calculations for the Turkish PAYG System, Working Paper, NFI.

Axel Borsch-Supan (2003). Life-Cycle Savings and Public Policy: A Cross-National Study of Six Countries, University of Chicago Press.

Auerbach, A. and Kotlikoff, L. (1983). An Examination of Empirical Test of Social Security and Savings. In Helpman, Elhanan, Razin, Sadka (eds.), Social Policy Evaluation: an economic perspective, p. 161-79.

Barro, R. (1974). Are Government Bonds Net Wealth? Journal of Political Economy, vol. 82(6).

Barro, R. (1978). The Impact of Social Security on Private Saving: Evidence from New the US Time Series, American Enterprise Institute, AIE Studies 199.

Barro, R. (1989). The Ricardian Approach to Budget Deficits, Journal of Economic Perspectives, vol. 3(2).

Boskin, M, Kotlikoff, L., Puffert, D., Shoven, J. (1985). Social Security: A Financial Appraisal Across and Within Generations. National Tax Journal, Vol. XL.

Boskin, M, Arvin, M. and Cone, K.(1983) Modeling Alternative Solutions to the Long-Run Social Security Problems, in M. Feldstein (ed.) Behavioral Simulation Methods in Tax Policy Analysis, Chicago: University of Chicago Press.

CBO memorandum, (1998). Social Security and Private Saving: A Review of the Empirical Evidence. Congressional Budget Office-USA.

Engen, E. and Gale, W. (1997). Effects of Social Security Reform on Private and National

Saving. Social Security Reform: Links to Saving, Investment and Growth, Federal Reserve Bank of Boston. June.

Feldstein, M. (1974). Social Security, Induced Retirement, and Aggregate Capital Accumulation. Journal of Political Economy. Vol.82, No.5. 
Feldstein, M. (1976a). Social Security and Saving: The Extended Life Cycle Theory. National Tax Journal. Vol.66, No.2.

Feldstein, M. (1976b). Social Security and Distribution of Wealth. Journal of the American Statistical Association. Vol.71 No.356.

Gruber, J. (2007). Public Finance and Public Policy. $2^{\text {nd }}$ Ed. Worth Publishers.

Hurd, M. and Shoven, J. (1985). The Distributional Impact of Social Security, in D.A. Wise (ed.), Pensions, Labor, and Individual Choice, Chicago: University of Chicago Press.

Kotlikoff, L. (2001). Generational Policy, Working Paper, NBER, No: 8163

Ministry of Labor and Social Security, (July 29, 2004). "Proposal for Reform in the Social Security System (Draft Text).

Modigliani, F. (1986). Life Cycle, Individual Thrift, and the Wealth of Nations. American Economic Review, Vol.76, No.3.

OECD (2005). Pensions at a Glance: Public Policies across OECD Countries. OECD Publishing.

Seidman, L. (1985). A General Equilibrium Critique of Feldstein's Social Security Estimate. Eastern Economic Journal, Vol. XI, No.2.

Seidman, L. (1999). Funding Social Security: A Strategic Alternative. Cambridge University Press.

Steuerle, C and Bakija, J. (1994). Retooling Social Security for the $21^{\text {st }}$ Century. The Urban Institute Press. Washington D.C.

The World Bank Report, (2000). Turkey Country Economic Memorandum. Report Number 20657-TU.

The World Bank Country Study, (2003). Non-Bank Financial Institutions and Capital Markets in Turkey.

TUSIAD (Turkiye Sanayicileri ve Isadamlari Dernegi) Report (2004). Turk Emeklilik Sisteminde Reform. Yayin No. TUSIAD-T/2004-11/382.

Williamson, S. and Jones, W. (1983). Computing the Impact of Social Security Using the Life Cycle Consumption Function. The American Economic Review. Vol.73. 